\author{
가열온도, 가열시간 및 부형제의 첨가량이 도축 반추위 내용물의 자일란, \\ 셀룰로오스 및 전분 분해효소 활성에 미치는 영향 \\ 원미영 ${ }^{1}$ 이도형 ${ }^{2} \cdot$ 김은중 $^{1} *$ \\ ${ }^{1}$ 경북대학교 축산학과, ${ }^{2}$ 전북대학교, 동물자원과학과
}

\title{
Effects of Temperature and Time for Heating and Filler Content on the Activities of Xylanase, Cellulase and Amylase in Slaughterhouse Rumen Content
}

\author{
Mi Young Won ${ }^{1}$, Do Hyung Lee ${ }^{2}$ and Eun Joong $\mathrm{Kim}^{1} *$ \\ ${ }^{1}$ Department of Animal Science, Kyungpook National University, Sangju, 742-711, Korea, \\ ${ }^{2}$ Department of Animal Science, Chonbuk National University, Jeonju, 561-756, Korea
}

\begin{abstract}
This study was conducted in order to develop slaughterhouse rumen content (SRC) as a potential feed additive. The moisture content of SRC can reach $80 \%$, and therefore an appropriate dewatering process is required before it can be used. In this study, the effects of heating temperature, heating time, and filler content during the dewatering process on the activity of various enzymes in SRC were investigated. The Box-Behnken experimental design was employed, involving a total of 45 experimental runs, consisting of three variables (heating time, heating temperature, and filler content) with three levels per variable (12, 30 and $48 \mathrm{hr} ; 60,75$ and $90^{\circ} \mathrm{C} ; 12,22.5$ and $33 \%$ for heating time, heating temperature, and filler content, respectively). For enzyme activities, xylanase, cellulase, and amylase were examined, and the results were subjected to an analysis of variance. Heating time, heating temperature and filler content had significant effects on the activity of each enzyme $(p<0.05)$. Cellulase and amylase activities decreased $(\mathrm{p}<0.05)$ at elevated heating temperatures, whereas xylanase was reasonably stable around $90^{\circ} \mathrm{C}$. The activities of all enzymes decreased $(\mathrm{p}<0.05)$ with increased heating time. Optimum filler contents for xylanase, cellulase, and amylase activities were $22.5,12$ and $33 \%$, respectively. However, optimum conditions for all variables that simultaneously maximize the activity of all three enzymes could not be ascertained in this study. Nevertheless, the results from the current study can be useful as basic information for the development of SRC as a feed additive enriched with improved major enzymes for livestock feed digestion.
\end{abstract}

(Key words : Dewatering conditions, Enzyme activity, Slaughterhouse rumen content, Heating)

\section{I. 서 론}

도축 과정에서 발생되는 반추위 내용물을 도축 반추위 내용물 (slaughterhouse rumen content, SRC)이라고 한다. $\mathrm{SRC}$ 의 영양소 함량은 건물기준으로 조단백질 함량이 10 $25 \%$, 조섬유 함량이 $30 \sim 40 \%$, 가용무질소물 함량이 $38 \sim 40$ $\%$, 지방 함량이 6 8\% 및 조회분 함량이 $8 \sim 13 \%$ 정도 포함 되어있다(Jovanović and Čuperlović, 1977). 또한 다양한 미 지성장인자, 발효산물 및 미생물에 의해 분비된 효소들을 함유하고 있다(Bryant and Doetsch, 1955; Ruf et al., 1953). $\mathrm{SRC}$ 의 가소화 에너지는 $2,670 \mathrm{kcal} / \mathrm{kg}$ (Kim et al., 2000)으
로, 반추동물이 이용할 수 있는 많은 양의 에너지를 포함 하고 있다(Klingerman et al., 2009). 이처럼 SRC의 사료적 잠재가치가 우수함에도 불구하고 지금까지 단순 유기성 폐 기물로 간주되어 폐기되거나 액비로 사용되어 왔으며, 그 에 따른 처리비용의 발생 등 경제적 손실을 초래해 왔다 (Adeniji and Jimoh, 2007; Shrestha et al., 2011). 그러나 우 리나라의 경우 2008 년 이후 개정된 사료관리법에 따라서 $\mathrm{SRC}$ 가 유해사료에서 제외되어, 현재에는 보조사료뿐만 아 니라 사료원료로서도 그 이용이 가능하게 되었다. 따라서 도축 부산물로 발생되는 반추위 내용물의 재활용 및 새로 운 사료자원으로서의 개발에 관한 연구가 절실히 요구되고

* Corresponding author: Eun Joong Kim, Department of Animal Science, Kyungpook National University, Sangju 742-711, Korea; Tel: +82-(0)54-530-1228; Fax: +82-(0)54-530-1229; E-mail: ejkim2011@knu.ac.kr 
있다.

한편, $\mathrm{SRC}$ 에 함유된 수분의 제거는 도축 반추위 내용물 의 수송, 가공 및 상품화에 있어서 매우 중요한 요인이다. 따라서 $\mathrm{SRC}$ 에 함유된 효소들의 활성을 유지하면서 효율적 으로 수분을 제거하는 방법의 개발은 도축 반추위 내용물 의 활용성 증진에 가장 중요한 요인이라 할 수 있다. 일반 적으로 효소와 같은 단백질들을 보호하면서 수분을 제거하 는 방법으로는 동결건조 방법이 널리 이용되고 있다 (Carpenter et al., 1993). 그러나 동결건조는 공정 비용이 상당하여 경제성 확보에 큰 어려움이 있다. 따라서 열건조 방법과 같이 보다 경제적인 방법이 적용되어야 한다.

본 연구에서는 $\mathrm{SRC}$ 를 가축사료, 특히 사일리지 및 $\mathrm{TMR}$ (total mixed ration)과 같은 반추동물 급여용 사료에 효소가 풍부한 첨가제 또는 대체사료로 활용하기 위한 방법을 개 발하기 위한 기초자료로써 다양한 가열 조건들이 도축 반 추위 내용물에 함유된 효소들에 미치는 영향을 조사하였다.

\section{ㅍ. 재료 및 방법}

\section{1. 도축 반추위액}

경상북도 구미에 소재한 도축장에서 채취된 반추위 내용 물을 보온병에 담아서 실험실로 옮긴 후에 건조과정 없이 cutter miller로 분쇄하여 입자도를 작게 하였다. 이때 공기 중의 산소 유입을 최소화하기 위하여 이산화탄소를 주사하 며 분쇄 작업을 수행하였다. 준비된 도축 반추위 내용물은 실험설계에 따라서 부형제 (말분)와 혼합한 후에 $250 \mathrm{~mL}$ 용 량의 유리용기 (aluminum seal stopper)에 실용량 $100 \mathrm{~mL}$ 로 담아 실험설계에 따라 정해진 온도와 시간 동안 가열처리 하였다. 가열처리는 항온수조에서 온도를 달리하여 수행하 였다. 실험설계의 조건은 Table 1에 표기하였다.

\section{2. 실험설계}

다양한 가열 조건에 대한 요인들로 열처리온도 $(60,75$, $\left.90^{\circ} \mathrm{C}\right)$ 열처리시간 $(12,30,48$ 시간) 및 부형제와의 혼합비율 $(12,22.5,33 \%)$ 을 선택하였고, 실험설계는 부분요인 분석 법 중 하나인 Box-Behnken 실험설계법(Box and Behnken, 1960)에 따라서 수행하였다. 실험설계법에 따라서 구성된 실험들과 각 실험들에 배치된 요인들의 수준은 Table 1에 서 보는 것과 같다. 모든 실험은 블록 없이 3 반복으로 하 여 총 45개의 실험을 구성하였다 (Table 1).

\section{3. 효소활성 측정}

실험이 완료된 혼합물들의 효소활성을 평가하였다. 효소 활성의 분석은 Son et al. (2006)의 방법에 따라 분석하였으 며 이를 요약하면 다음과 같다. 전분 분해효소 측성 시에 는 soluble starch (Difco), 셀룰로오스 분해효소 측정 시에는 carboxymethyl cellulose (CMC, Sigma) 그리고 xylan 분해효 소 측정 시에는 birch wood xylan (Sigma)을 기질로 사용하 였다. 전분 분해효소와 xylan 분해효소 측정 시에는 기질을 $10 \mathrm{mM}$ Tris- $\mathrm{HCl}(\mathrm{pH}$ 7.0)에 $1 \%$ 혼합하여 기질 용액을 제 조하였고, 셀룰로오스 분해효소의 경우에는 기질을 $0.5 \%$ 혼합하여 제조하였다. 효소반응은 시료 $1 \mathrm{~g}$ 에 기질용액 9 $\mathrm{ml}$ 을 혼합한 후에 $37^{\circ} \mathrm{C}$ 에서 1시간 동안 반응시킨 후 $(150$ $\mathrm{rpm})$ 에 원심분리 $(10,000 \mathrm{rpm}-5 \mathrm{~min})$ 하여 상등액을 분리하였 다. 다시 상등액 $300 \mu \mathrm{L}$ 와 DNS 용액 (3,5-dinitrosalicylic acid, $1 \%$; sodium sulfate, $0.05 \%$; sodium hydroxide, $1 \%$ ) $300 \mu \mathrm{L}$ 를 혼합한 후에 $90^{\circ} \mathrm{C}$ 에서 10 분간 반응시켰다. 반응 액을 상온으로 냉각한 후에 $40 \%$ potassium sodium tartrate 용액 $50 \mu \mathrm{L}$ 를 혼합한 후 $0.45 \mu \mathrm{m}$ filter로 불순물을 제거하 고 $575 \mathrm{~nm}$ 에서 흡광도를 측정하였다. 혼합물에 존재하는 환원당에 의한 background는 기질을 포함하지 않은 $10 \mathrm{mM}$ Tris- $\mathrm{HCl}(\mathrm{pH}$ 7.0) 용액과 반응한 용액의 흡광도를 이용하 여 배제하였다. 효소반응을 통하여 유리된 당 (sugar)의 농 도는 회귀방정식을 이용하여 평가하였으며, 각 효소 별로 사용된 표준물질로서 전분 분해효소와 셀룰로오스 분해효 소는 포도당을 사용하였고, xylan 분해효소는 xylose를 표 준물질로 사용하였다. 효소활성 단위 1 unit $(\mathrm{U})$ 는 분당 시 료 $1 \mathrm{~g}$ 으로부터 생성된 $1 \mu \mathrm{M}$ glucose 혹은 xylose로 나타내 었다.

\section{4. 통계분석}

각 요인들의 효과에 대한 유의성은 분산분석을 통하여 검정하였으며, 각 요인들의 개별적인 주 효과, 곡률효과 및 상호관계는 반응표면모형 (response surface model)을 근사 화하여 산출하였다. 실험결과의 분석은 Minitab, version 14 (Minitab Inc., 2010) 통계 프로그램을 사용하였다.

\section{III. 결과 및 고찰}

\section{1. 효소활성}

도축 반추위 내용물을 분쇄한 후, 부형제와 혼합하였고 
다양한 온도에서 가열한 후에 효소활성을 분석하였다. 도 (BBD)을 이용하였다. $\mathrm{BBD}$ 에 따라서 총 15 개의 서로 다른 축 반추위 내용물과 부형제의 혼합비율, 가열온도 및 가열 변수들의 조합을 설계하였고, 각 실험당 3 반복으로 구성하 시간을 변수로 설정하였다. 각 변수들이 도축 반추위액에 여 총 45 개의 실험을 구성하였다. 실험설계법에 의하여 얻 포함된 효소들의 활성에 미치는 효과들은 각 변수들의 주 어진 총 45개의 실험들에서 분석된 효소활성은 (xylan 분해 효과와 곡률효과 및 상호작용 효과 등을 분석하기 위하여 효소, 셀룰로오스 분해효소, 전분 분해효소) Table 1에서 부분 요인 실험설계법 중 하나인 Box-Behnken design 보는 것과 같다. 가장 우수한 활성을 나타낸 효소는 전분

Table 1. Box-Behnken experimental design and their responses for enzyme activities

\begin{tabular}{|c|c|c|c|c|c|c|}
\hline \multirow{2}{*}{ Run } & \multicolumn{3}{|c|}{ Variables and their levels } & \multicolumn{3}{|c|}{ Responses of enzyme activities, $U$} \\
\hline & Heat & Time & Filler & Xylanase & Cellulase & Amylase \\
\hline 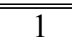 & 60 & 12 & 22.5 & 222.7 & 109.9 & 405.3 \\
\hline 2 & 90 & 12 & 22.5 & 291.5 & 78.3 & 276.6 \\
\hline 3 & 60 & 48 & 22.5 & 222.7 & 99.4 & 331.4 \\
\hline 4 & 90 & 48 & 22.5 & 235.2 & 71.9 & 335.7 \\
\hline 5 & 60 & 30 & 12.0 & 264.4 & 84.6 & 329.3 \\
\hline 6 & 90 & 30 & 12.0 & 262.3 & 59.3 & 266.0 \\
\hline 7 & 60 & 30 & 33.0 & 210.2 & 74.1 & 382.1 \\
\hline 8 & 90 & 30 & 33.0 & 206.0 & 65.6 & 242.8 \\
\hline 9 & 75 & 12 & 12.0 & 224.8 & 65.6 & 333.5 \\
\hline 10 & 75 & 48 & 12.0 & 226.9 & 65.6 & 339.9 \\
\hline 11 & 75 & 12 & 33.0 & 274.8 & 40.3 & 312.4 \\
\hline 12 & 75 & 48 & 33.0 & 206.0 & 67.7 & 377.8 \\
\hline 13 & 75 & 30 & 22.5 & 270.6 & 69.8 & 398.9 \\
\hline 14 & 75 & 30 & 22.5 & 243.5 & 53.0 & 263.9 \\
\hline 15 & 75 & 30 & 22.5 & 293.5 & 42.4 & 259.7 \\
\hline 16 & 60 & 12 & 22.5 & 224.8 & 112.0 & 407.4 \\
\hline 17 & 90 & 12 & 22.5 & 295.6 & 74.1 & 280.8 \\
\hline 18 & 60 & 48 & 22.5 & 220.6 & 93.0 & 335.7 \\
\hline 19 & 90 & 48 & 22.5 & 239.4 & 71.9 & 339.9 \\
\hline 20 & 60 & 30 & 12.0 & 262.3 & 90.9 & 327.2 \\
\hline 21 & 90 & 30 & 12.0 & 270.6 & 57.2 & 259.7 \\
\hline 22 & 60 & 30 & 33.0 & 210.2 & 71.9 & 386.3 \\
\hline 23 & 90 & 30 & 33.0 & 199.8 & 71.9 & 255.5 \\
\hline 24 & 75 & 12 & 12.0 & 229.0 & 67.7 & 339.9 \\
\hline 25 & 75 & 48 & 12.0 & 222.7 & 63.5 & 335.7 \\
\hline 26 & 75 & 12 & 33.0 & 268.5 & 38.2 & 304.0 \\
\hline 27 & 75 & 48 & 33.0 & 204.0 & 71.9 & 386.3 \\
\hline 28 & 75 & 30 & 22.5 & 249.8 & 67.7 & 405.3 \\
\hline 29 & 75 & 30 & 22.5 & 243.5 & 59.3 & 259.7 \\
\hline 30 & 75 & 30 & 22.5 & 289.4 & 46.6 & 268.1 \\
\hline 31 & 60 & 12 & 22.5 & 222.7 & 105.7 & 411.6 \\
\hline 32 & 90 & 12 & 22.5 & 293.5 & 71.9 & 272.4 \\
\hline 33 & 60 & 48 & 22.5 & 212.3 & 97.3 & 339.9 \\
\hline 34 & 90 & 48 & 22.5 & 243.5 & 67.7 & 337.8 \\
\hline 35 & 60 & 30 & 12.0 & 258.1 & 86.7 & 335.7 \\
\hline 36 & 90 & 30 & 12.0 & 270.6 & 50.8 & 263.9 \\
\hline 37 & 60 & 30 & 33.0 & 216.5 & 67.7 & 388.4 \\
\hline 38 & 90 & 30 & 33.0 & 216.5 & 67.7 & 251.3 \\
\hline 39 & 75 & 12 & 12.0 & 241.5 & 63.5 & 337.8 \\
\hline 40 & 75 & 48 & 12.0 & 218.5 & 67.7 & 342.0 \\
\hline 41 & 75 & 12 & 33.0 & 266.5 & 42.4 & 299.8 \\
\hline 42 & 75 & 48 & 33.0 & 220.6 & 67.7 & 386.3 \\
\hline 43 & 75 & 30 & 22.5 & 268.5 & 67.7 & 394.7 \\
\hline 44 & 75 & 30 & 22.5 & 251.9 & 55.1 & 261.8 \\
\hline 45 & 75 & 30 & 22.5 & 299.8 & 42.4 & 261.8 \\
\hline
\end{tabular}


분해효소로서 실험들간의 평균(표준편차)은 325.2(51.9) U 로 나타났다. 다음으로는 xylan 분해효소 활성이 우수하였 으며 실험들간의 평균은 244.1 (28.8) U로 나타났다. 셀룰로 오스 분해효소 활성은 가장 낮게 나타났으며, 실험들간의 평균은 69.5 (17.6) $\mathrm{U}$ 로 나타났다.

실제 도축 반추위 내용물의 활용법 중, 가장 단순한 방 법으로 건조 분쇄 공정을 거친 후에 다시 반추동물 사료에 첨가하는 방법을 들 수 있다. 도축 반추위 내용물을 단순 건조하여 면양사료에 $4 \%$ 까지 첨가한 결과 사료섭취량, 일 당증체량 등에 아무런 영향을 미치지 않은 것으로 보고된 바 있다(Salinas-Chavira et al., 2007). Rincon et al. (2010) 의 연구에서는 비육우의 경우, 급여되는 조사료의 $30 \%$ 까지 건조된 반추위 내용물로 대체가 가능한 것으로 나타났다. 그 외에 SRC는 Aspergillus oryzae와 같은 생균제의 배양원 료로도 사용이 가능한 것으로 보고되었다(Kim et al., 2000). 특히 SRC에는 반추위 내 미생물들에 의해서 분비된 다양한 소화 효소들이 상당량 잔류하고 있다(Forsberg and Cheng, 1992). 따라서 이러한 효소들을 활용하면 SRC를 사 료첨가용 효소제로서 활용이 가능하다. 반추동물에 있어 xylanase, cellulase 및 amylase와 같은 효소제의 사료 첨가 는 영양소의 소화율을 향상 시키며 (Arriola et al., 2011) 이 용효율을 향상시켜 생산성을 증가시킬 수 있다(Yang et al., 1999). 전분 분해효소의 사료 첨가는 착유우에 있어 유 생산량 향상 (Gencoglu et al., 2010; Weiss et al., 2011), 일 당증체량 향상 (Holtshausen et al., 2011) 등의 효과가 있는
것으로 보고된 바 있다. 그리고 셀룰로오스 분해효소의 첨 가는 반추동물에 있어 셀룰로오스 이용을 높이며, 단백질 분해율 향상 및 어린 동물의 성장을 향상시킨다고 보고된 바 있다(Klingerman et al., 2009; Schingoethe et al., 1999; Titi and Lubbadeh, 2004). 따라서 반추동물의 생산성 향상 을 위한 사료첨가용 효소제 개발에 대한 많은 연구가 진행 되고 있다(Bhatta et al., 2005; Santra et al., 2007). 그러나 효소활성이 나타났다고 하여 도축 반추위 내용물을 조제 시판되는 사료 첨가용 효소제와 직접 비교하는 것은 효소 활성에 있어 큰 차이를 보이므로 확대해석을 경계해야 하 며 선행연구 (Salinas-Chavira et al., 2007)에서도 나타났듯 이 열처리 등의 가공에도 일정량의 효소활성을 보이는 폐 자원을 이용한 대체사료 원료로서의 가능성에 보다 중점을 두어야 한다고 사료된다.

\section{Xylan 분해효소 활성}

Xylan 분해효소활성에 대한 변수들의 효과에 대한 분산 분석에서 변수들의 효과, 회귀모형, 선형효과, 곡률효과 및 상호관계 모두에서 $95 \%$ 이상의 통계적 유의성이 나타났다 (Table 2). 이에 보다 정확한 변수들의 효과를 조사하기 위 하여, 총 45 개의 실험들에서 얻어진 xylan 분해효소 활성값 들을, 적용된 변수들의 수준들을 이용하여 반응표면모형을 근사화하였고, 그 결과로 얻어진 회귀계수들과 그 확률값 들은 Table 3에서 보는 것과 같다. 주 효과에서는 모든 변

Table 2. Analysis of variance ${ }^{1)}$ for the effect of variables on xylanase activity from slaughterhouse rumen content

\begin{tabular}{lrrrrr}
\hline \multicolumn{1}{c}{ Source } & DF & SS & MS & F value & p-value \\
\hline \hline Regression & 9 & 22757 & 2528.6 & 6.08 & $<0.01$ \\
Linear & 3 & 11969 & 2401.6 & 5.77 & $<0.01$ \\
Quadratic & 3 & 6945 & 2314.8 & 5.56 & 0.04 \\
Interaction & 3 & 3843 & 1281.1 & 3.08 & \\
Residual error & 35 & 14567 & 416.2 & & \\
Total & 44 & 37324 & & & \\
\hline
\end{tabular}

${ }^{1)} \mathrm{DF}$, degree of freedom; SS, sum of square; MS, mean of square.

Table 3. Regression coefficients and their probabilities for the response of xylanase activity

\begin{tabular}{|c|c|c|c|c|}
\hline Term & Coefficient & Standard error & $\mathrm{T}$ value & $\mathrm{p}$-value \\
\hline Constant & -306.407 & 177.895 & -1.722 & 0.094 \\
\hline Heat & 9.364 & 4.232 & 2.213 & 0.034 \\
\hline Time & 6.618 & 2.214 & 3.116 & 0.004 \\
\hline Filler & 10.625 & 3.893 & 2.729 & 0.010 \\
\hline Heat $\times$ Heat & -0.046 & 0.027 & -1.671 & 0.104 \\
\hline Time $\times$ Time & -0.043 & 0.019 & -2.266 & 0.030 \\
\hline Filler $\times$ Filler & -0.184 & 0.056 & -3.314 & 0.002 \\
\hline Heat $\times$ Time & -0.046 & 0.022 & -2.093 & 0.044 \\
\hline Heat $\times$ Filler & -0.018 & 0.037 & -0.472 & 0.064 \\
\hline Time $\times$ Filler & -0.067 & 0.031 & -2.152 & 0.038 \\
\hline
\end{tabular}


수들에서 유의성이 나타났다 $(\mathrm{p}<0.05)$. 곡률효과에 있어서는 시간(time)과 부형제 혼합비율(filler)에서 유의적인 효과가 나타났다 $(\mathrm{p}<0.05)$, 상호작용에 있어서는 온도와 시간(heat $\times$ time) 그리고 시간과 부형제 혼합비율 $($ time $\times$ filler)에서 유 의성이 나타났다 $(\mathrm{p}<0.05)$. 각각의 요인들의 개별적인 효과 는 Fig. $1 \mathrm{~A}$ 에서 보는 것과 같다. Xylan 분해효소에 대한 온도의 효과는 $60^{\circ} \mathrm{C}$ 에서 $90^{\circ} \mathrm{C}$ 로 증가할수록, 효소활성이 향상되는 것으로 나타났다. 반면 열처리시간은 12 시간에서 48시간으로 증가할수록 효소활성이 낮아지는 것으로 나타 났다. 마지막으로 부형제의 비율은 $12 \%$ 에서 $33 \%$ 중간 정 도에서 가장 우수한 효소활성을 나타내었다. 실험에 사용 된 요인들간의 상호작용은 반응표면모형 근사화 결과에서 얻어진 유의성을 바탕으로 온도와 시간 그리고 시간과 부 형제의 함량을 분석하였고, 그 결과는 각각 Fig. $2 \mathrm{~A}$ 와 $2 \mathrm{~B}$ 에서 보는 것과 같다. 요인들의 개별적인 효과는 그림에서 와 같이 온도 $85^{\circ} \mathrm{C}$ 이상과 열처리 20 시간 미만에서 가장 우수한 효소활성을 나타내었다. 반면, 열처리시간과 부형제 함량과의 관계에서는 40 시간 미만의 가열시간과 $15 ~ 30 \%$ 사이의 조건에서 가장 우수한 효소활성을 나타내었다.

\section{3. 셀룰로오스 분해효소 활성}

셀룰로오스 분해효소 활성에 대한 변수들의 효과에 대한 분산분석에서 변수들의 효과 회귀모형, 선형효과, 곡률효과 및 상호관계 모두에서 $95 \%$ 이상의 통계적 유의성이 나타 났다 (Table 4). 이에 보다 정확한 변수들의 효과를 조사하 기 위하여, 총 45 개의 실험들에서 얻어진 셀룰로오스 분해 효소 활성값들을, 적용된 변수들의 수준들을 이용하여 반 응표면모형을 근사화하였고, 그 결과로 얻어진 회귀계수들 과 그 확률값들은 Table 5에서 보는 것과 같다. 주 효과에 서는 온도와 시간에서 유의성이 나타났으며 $(\mathrm{p}<0.05)$, 부형 제 함량의 효과는 유의적이지 않은 것으로 나타났다 $(\mathrm{p}>0.05)$. 곡률효과는 모든 요인들에서 유의성이 나타났다
(A)

(B)

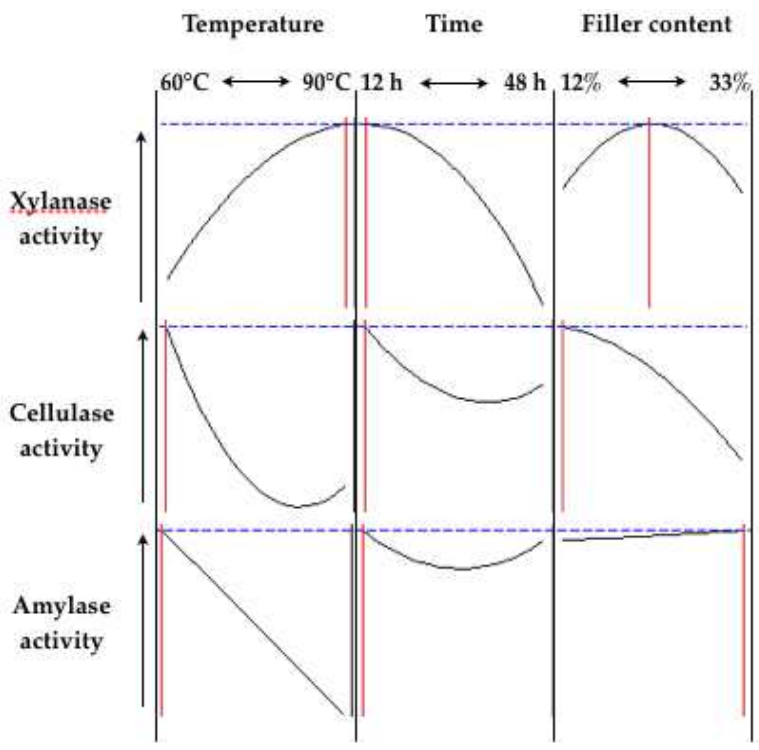

Fig. 1. Effects of heating temperature, heating time and filler content on enzyme activities from slaughterhouse rumen content. (A), (B) and (C) indicate xylanase, cellulase and amylase activity, respectively.

$(\mathrm{p}<0.05)$. 상호작용에 있어서는 온도와 부형재 함량 그리고 기간과 부형제의 함량에서 유의적인 효과가 나타났다 $(\mathrm{p}<0.05)$. 각 요인들의 개별적인 효과는 Fig. $1 \mathrm{~B}$ 에서 보는 것과 같다. 셀룰로오스 분해효소에 대한 온도의 효과는 $60^{\circ} \mathrm{C}$ 에서 $90^{\circ} \mathrm{C}$ 로 증가할수록, 효소활성이 급격하게 감소하 는 것으로 나타났다. 열처리시간 또한 12 시간에서 48 시간 으로 증가할수록 효소활성이 낮아지는 것으로 나타났다. 마지막으로 부형제의 비율은 $12 \%$ 에서 가장 우수한 효소활 성을 나타내었다. 실험에 사용된 요인들간의 상호작용은 반응표면모형 근사화 결과에서 얻어진 유의성을 바탕으로 온도와 부형제 그리고 시간과 부형제의 함량을 분석하였고, 그 결과는 각각 Fig. $2 \mathrm{C}$ 와 $2 \mathrm{D}$ 에서 보는 것과 같다. 온도 $60^{\circ} \mathrm{C}$ 미만과 부형제 함량 $20 \%$ 미만에서 가장 우수한 효소

Table 4. Analysis of variance ${ }^{1)}$ for the effect of variables on cellulase activity from slaughterhouse rumen content

\begin{tabular}{lrrrrr}
\hline \multicolumn{1}{c}{ Source } & DF & SS & MS & F value & p-value \\
\hline \hline Regression & 9 & 11681 & 1297.89 & 19.57 & $<0.01$ \\
Linear & 3 & 3674 & 2160.81 & 32.58 & $<0.01$ \\
Quadratic & 3 & 6707 & 2235.60 & 33.71 & $<0.01$ \\
Interaction & 3 & 1300 & 433.46 & 6.54 & $<0.01$ \\
Residual error & 35 & 2321 & 66.31 & & \\
Total & 44 & 14002 & & & \\
\hline
\end{tabular}

${ }^{1)} \mathrm{DF}$, degree of freedom; SS, sum of square; MS, mean of square. 
Table 5. Regression coefficients and their probability for the response of cellulase activity

\begin{tabular}{|c|c|c|c|c|}
\hline Term & Coefficient & Standard error & $\mathrm{T}$ value & $\mathrm{p}$-value \\
\hline Constant & 768.937 & 71.0104 & 10.829 & $<0.01$ \\
\hline Heat & -16.159 & 1.16894 & -9.565 & $<0.01$ \\
\hline Time & -3.625 & 0.8477 & -9.923 & $<0.01$ \\
\hline Filler & -2.247 & 1.5540 & -1.446 & 0.157 \\
\hline Heat $\times$ Heat & 0.094 & 0.0109 & 8.646 & $<0.01$ \\
\hline Time $\times$ Time & 0.033 & 0.0076 & 4.335 & $<0.01$ \\
\hline Filler $\times$ Filler & -0.058 & 0.0222 & -2.635 & 0.012 \\
\hline Heat $\times$ Time & 0.008 & 0.0087 & 0.897 & 0.376 \\
\hline Heat $\times$ Filler & 0.046 & 0.0149 & 3.066 & 0.004 \\
\hline Time $\times$ Filler & 0.038 & 0.0124 & 3.066 & 0.004 \\
\hline
\end{tabular}

(A)

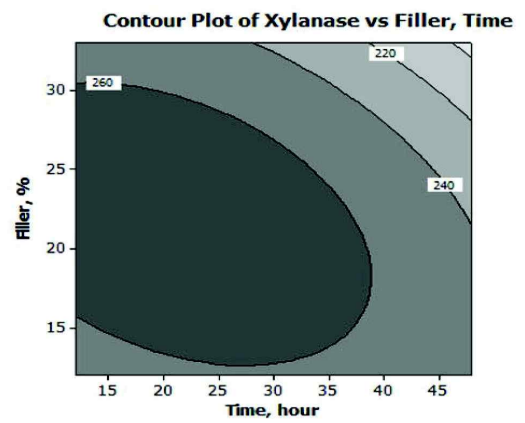

(C)

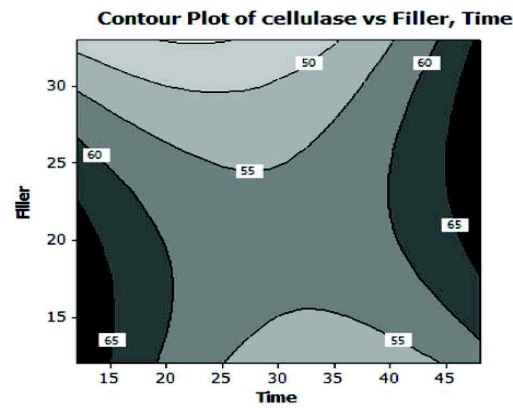

(E)

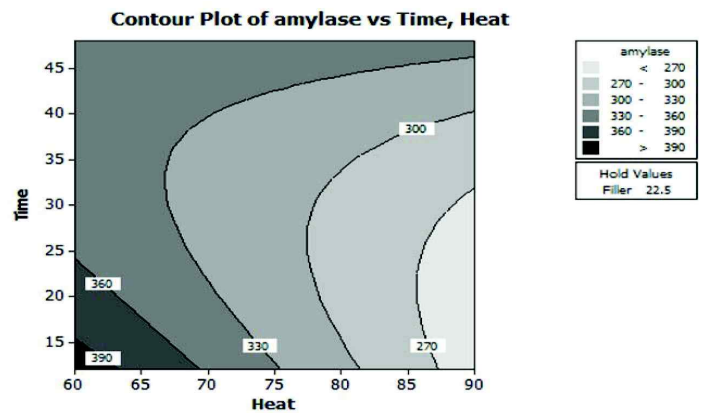

(B)
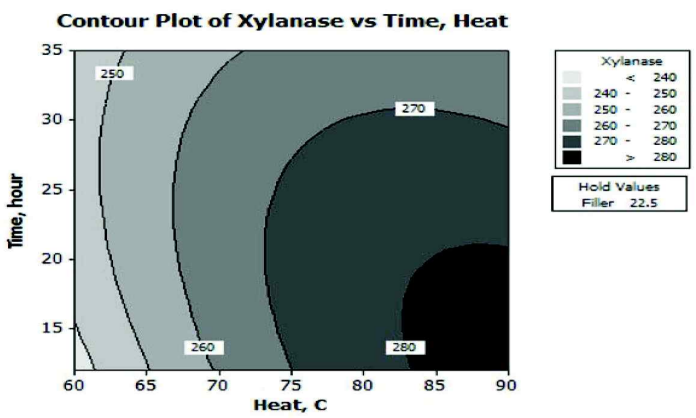

(D)

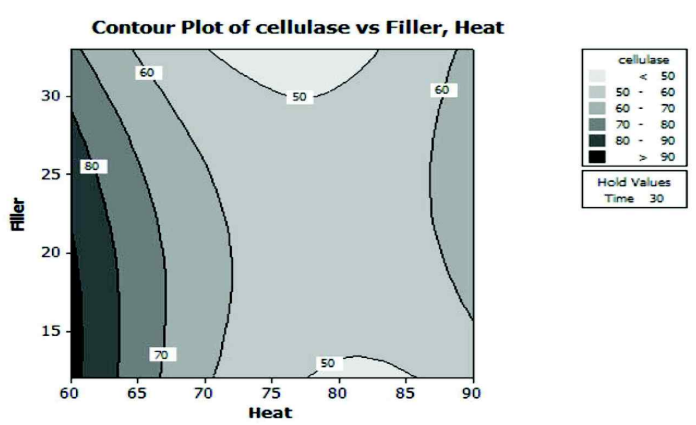

Fig. 2. Contour plots for the interactions among variables on enzyme production from slaughterhouse rumen content. (A) and (B) indicate the interactions between heating time and filler content, and between heating temperature and time on xylanase activity, respectively. (C) and (D) indicate the interactions between heating time and filler content, and between heating temperature and filler content on cellulase activity, respectively. (E) indicates the interaction between heating temperature and heating time on amylase activity. 
활성을 나타내었다. 또한 15 시간 이하의 열처리시간과 $22 \%$ 미만의 부형제 함량 조건 그리고 45시간 이상의 열처리시 간과 $22 \%$ 이상의 부형제 함량에서 효소활성이 높게 나타 났다.

\section{4. 전분 분해효소 활성}

전분 분해효소 활성에 대한 변수들의 효과에 대한 분산 분석에서 변수들의 효과 회귀모형, 선형효과, 곡률효과 및 상호관계 모두에서 $95 \%$ 이상의 통계적 유의성이 나타났다 (Table 6). 이에 보다 정확한 변수들의 효과를 조사하기 위 하여, 총 45 개의 실험들에서 얻어진 xylan 분해효소 활성값 들을, 적용된 변수들의 수준들을 이용하여 반응표면모형을 근사화 하였고, 그 결과로 얻어진 회귀계수들과 그 확률값 들은 Table 7에서 보는 것과 같다. 주효과 및 곡률효과 모 두에서 가열시간만이 유의적인 효과를 나타내었다 $(\mathrm{p}<0.05)$ 상호작용에 있어서는 열처리온도와 시간에서 유의적인 효 과가 나타났다 $(\mathrm{p}<0.05)$. 각 요인들의 개별적인 효과에 대한 그림은 Fig. $1 \mathrm{C}$ 에서 보는 것과 같다. 가열온도를 증가할수 록 효소활성은 급격하게 낮아짐을 알 수 있었다. 가열시간 은 양극점에서 활성이 높은 형태를 나타내었으나, 12시간 에서 비교적 높은 활성을 나타내었다. 마지막으로 부형제
의 함량이 증가할수록 효소활성이 높게 나타났다. 실험에 사용된 요인들간의 상호작용은 반응표면모형 근사화 결과 에서 얻어진 유의성을 바탕으로 온도와 부형제 그리고 시 간과 부형제의 함량을 분석하였고, 그 결과는 각각 Fig. $2 \mathrm{E}$ 에 표기하였는데 열처리온도와 열처리시간은 각각의 요인 들이 가질 수 있는 최소값에서 가장 우수한 효소활성이 나 타났다.

본 실험의 결과들을 종합해보면 처리과정을 달리할 경우 도축 반추위 내용물을 폐기물로 처리하지 않고 가축사료 첨가용 효소제의 생산 기질로 재활용할 수 있는 잠재성이 있는 것으로 여겨진다. 반추위 내용물에 포함된 다양한 미 지영양인자까지 고려하면 반추동물 사료효율 개선 및 생산 성 향상, 그리고 사료비 절감을 통한 생산비의 절감에 기 여하는, 특히 사료분해 효소가 풍부한, 사료첨가제로서 이 용이 가능할 것으로 사료된다. 그러나 도축 반추위 내용물 의 수거과정에서 발생하는 비용 또한 고려하여야 하며, 내 용물에 존재하는 휘발성지방산의 영향으로 인한 가축의 섭 취량 문제 또한 현장 적용 시에 고려되어야 할 사항이다. 향후 적절한 발효 또는 가공과정 및 제형과정을 거친 후 사일리지, TMR 등 반추동물의 사료에 첨가하여 사양실험 을 통한 유, 육 생산성에 미치는 효과를 분석하고, 개발된 기술의 효능을 검증하는 추가적인 연구가 필요할 것으로

Table 6. Analysis of variance ${ }^{1)}$ for the effect of variables on amylase activity from slaughter rumen content

\begin{tabular}{lrcccc}
\hline \multicolumn{1}{c}{ Source } & DF & SS & MS & F value & p-value \\
\hline \hline Regression & 9 & 77558 & 8618 & 6.91 & $<0.01$ \\
Linear & 3 & 44372 & 9726 & 7.80 & $<0.01$ \\
Quadratic & 3 & 11980 & 3993 & 3.20 & 0.035 \\
Interaction & 3 & 21206 & 7069 & 5.67 & $<0.01$ \\
Residual error & 35 & 43643 & 1247 & & \\
Total & 44 & 121201 & & & \\
\hline
\end{tabular}

${ }^{1)} \mathrm{DF}$, degree of freedom; SS, sum of square; MS, mean of square.

Table 7. Regression coefficients and their probabilities for the response of amylase activity

\begin{tabular}{lcccc}
\hline \multicolumn{1}{c}{ Term } & Coefficient & Standard error & T value & $\mathrm{p}$-value \\
\hline \hline Constant & 710.364 & 307.924 & 2.307 & 0.027 \\
Heat & -3.168 & 7.326 & -0.432 & 0.668 \\
Time & -17.1 & 3.676 & -4.652 & $<0.01$ \\
Filler & 5.572 & 6.738 & 0.827 & 0.414 \\
Heat $\times$ Heat & -0.006 & 0.047 & -0.124 & 0.902 \\
Time $\times$ Time & 0.101 & 0.033 & 3.074 & 0.004 \\
Filler $\times$ Filler & 0.004 & 0.096 & 0.041 & 0.967 \\
Heat $\times$ Time & 0.124 & 0.038 & 3.277 & 0.002 \\
Heat $\times$ Filler & -0.108 & 0.065 & -1.673 & 0.103 \\
Time $\times$ Filler & 0.1 & 0.054 & 1.863 & 0.071 \\
\hline
\end{tabular}


사료된다.

$$
\text { IV. 요 약 }
$$

본 연구는 도축장에서 폐기되는 도축 반추위 내용물을 사일리지 혹은 TMR (total mixed ration) 사료 첨가용 효소 제로 개발하기 위한 목적으로 수행되었다. 도축 반추위 내 용물에는 상당한 수분이 함유되어 있어, 적절한 건조과정 을 거치지 않고서는 그 활용이 원활하지 않다. 그러나 효 소는 열에 민감한 단백질로 구성되어 있기 때문에 적절한 건조 조건의 개발이 필요하다. 본 연구에서는 통계적 방법 을 이용하여 가열온도 $\left(60,75,90^{\circ} \mathrm{C}\right)$, 가열시간 $(12,30,48$ 시간) 및 부형제의 비율 $(12,22.5,33 \%)$ 이 도축 반추위 내 용물에 함유된 다양한 효소활성에 미치는 효과를 분석하였 다. 총 3 가지 효소, xylan 분해효소, 셀룰로오스 분해효소 및 전분 분해효소를 검토하였고, 각 효소활성들에 대한 각 요인들의 효과가 매우 다양하게 나타났다 $(\mathrm{p}<0.05)$. 셀룰로 오스 분해효소와 전분 분해효소의 활성은 가열온도가 증가 함에 따라 감소하였으며 $(\mathrm{p}<0.05)$, xylan 분해해소는 열에 대한 안전성이 다른 효소들에 비하여 우수하였다. 자일란, 셀룰로오스, 전분 분해효소를 증가시키는 적정 부형제의 비율은 22.5, 12 그리고 33\%로 나타났다. 비록 3가지 효소 들의 제형화에 있어 공통적으로 적용될 수 있는 최적점을 도출하지는 못하였으나, 본 연구결과에서 얻어진 효소들의 반응 값들을 이용하여 목적하는 효소에 따라서 다양한 방 법으로 적용이 가능할 것으로 판단된다.

$$
\mathrm{V} \text {. 사 사 }
$$

본 연구는 농림수산식품부 생명산업기술개발사업 (신진연 구자지원, 과제번호: 111113-1)에 의해 수행되었으며 이에 감사 드립니다.

\section{VI. 인 용 문 헌}

Adeniji, A.A. and Jimoh, A. 2007. Effects of replacing maize with enzyme-supplemented bovine rumen content in the diets of pullet chicks. International Journal of Poultry Science. 6:814-817.

Arriola, K.G., Kim, S.C., Staples, C.R. and Adesogan, A.T. 2011.

Effect of fibrolytic enzyme application to low- and high-concentrate diets on the performance of lactating dairy cattle. Journal of Dairy Science. 94:832-841.

Bhatta, R., Vaithiyanathan, S., Shinde, A.K. and Jakhmola, R.C. 2005. Effect of feeding complete feed block containing Prosopis cineraria leaves and polyethylene glycol (PEG)-6000 on nutrient intake, its utilization, rumen fermentation pattern and rumen enzyme profile in kids. Journal of the Science of Food and Agriculture. 85:1788-1794.

Box, G.E.P. and Behnken, D.W. 1960. Some new three level designs for the study of quantitative variables. Technometrics. 2:455-475.

Bryant, M.P. and Doetsch, R.N. 1955. Factors necessary for the growth of Bacteroides succinogenes in the volatile acid fraction of rumen fluid. Journal of Dairy Science. 38:340-350.

Carpenter, J.F., Prestrelski, S.J. and Arakawa, T. 1993. Separation of freezing- and drying-induced denaturation of lyophilized proteins using stress-specific stabilization: I. Enzyme activity and calorimetric studies. Archives of Biochemistry and Biophysics. 303:456-464.

Forsberg, C.W. and Cheng, K.J. 1992. Molecular strategies to optimise forage and cereal digestion by ruminants, In: Bills, D.D. and Kung, S.D. (Eds.) Biotechnology and Nutrition, Butterworth Heinmann Stoneham, UK. pp. 107-147.

Gencoglu, H., Shaver, R.D., Steinberg, W., Ensink, J., Ferraretto, L.F., Bertics, S.J., Lopes, J.C. and Akins, M.S. 2010. Effect of feeding a reduced-starch diet with or without amylase addition on lactation performance in dairy cows. Journal of Dairy Science. 93:723-732.

Holtshausen, L., Chung, Y.H., Gerardo-Cuervo, H., Oba, M. and Beauchemin, K.A. 2011. Improved milk production efficiency in early lactation dairy cattle with dietary addition of a developmental fibrolytic enzyme additive. Journal of Dairy Science. 94:899-907.

Jovanović, M. and Čuperlović, M. 1977. Nutritive value of rumen contents for monogastric animals. Animal Feed Science and Technology. 2:351-360.

Kim, B., Chung, K. and Shin, H. 2000. Study on the development of Aspergillus oryzae culture with rumen contents from slaughterhouse. Journal of Animal Science and Technology (Kor.). 42:85-92

Klingerman, C.M., Hu, W., McDonell, E.E., DerBedrosian, M.C. and Kung, L. 2009. An evaluation of exogenous enzymes with amylolytic activity for dairy cows. Journal of Dairy Science. 92: 1050-1059.

Minitab Inc. 2010. Meet Minitab 16. State College, PA, Minitab Inc. (www.minitab.com).

Rincon, F.G.R., Bermudez-Hurtado, R.M., Estrada-Angulo, A., Juarez-Reyes, A.S. and Pujol-Manriquez, C. 2010. Dried ruminal contents as a substitute for alfalfa hay in growing-finishing diets for feedlot cattle. Journal of Animal and Veterinary Advances. 9:1526-1530 
Ruf, E.W., Hale, W.H. and Burroughs, W. 1953. Observations upon an unidentified factor in feedstuffs stimulatory to cellulose digestion in the rumen and improved liveweight gains in lambs. Journal of Animal Science. 12:731-739.

Salinas-Chavira, J., Dominguez-Munoz, M., Bernal-Lorenzo, R., Garcia-Castillo, R.F. and Arzola-Alvarez, C. 2007. Growth performance and carcass characteristics of feedlot lambs fed diets with pig manure and rumen contents. Journal of Animal and Veterinary Advances. 6:505-508.

Santra, A., Karim, S.A. and Chaturvedi, O.H. 2007. Rumen enzyme profile and fermentation characteristics in sheep as affected by treatment with sodium lauryl sulfate as defaunating agent and presence of ciliate protozoa. Small Ruminant Research. 67:126137.

Schingoethe, D.J., Stegeman, G.A. and Treacher, R.J. 1999. Response of lactating dairy cows to a cellulase and xylanase enzyme mixture applied to forages at the time of feeding. Journal of Dairy Science. 82:996-1003.

Shrestha, K., Shrestha, P., Adetutu, E.M., Walsh, K.B., Harrower,
K.M., Ball, A.S. and Midmore, D.J. 2011. Changes in microbial and nutrient composition associated with rumen content compost incubation. Bioresource Technology. 102:3848-3854.

Son, H.J., Song, J.Y., Choi, N.J., Ha, J.K. and Chang, J.S. 2006. Comparison of the influences of carbon substrates on the fibrolytic activities of Neocallimastix sp. NLRI-3. Journal of Animal Science and Technology (Kor.). 48:415-424.

Titi, H. and Lubbadeh, W.F. 2004. Effect of feeding cellulase enzyme on productive responses of pregnant and lactating ewes and goats. Small Ruminant Research. 52:137-143.

Weiss, W.P., Steinberg, W. and Engstrom, M.A. 2011. Milk production and nutrient digestibility by dairy cows when fed exogenous amylase with coarsely ground dry corn. Journal of Dairy Science. 94:2492-2499.

Yang, W.Z., Beauchemin, K.A. and Rode, L.M. 1999. Effectsof an enzyme feed additive on extent of digestion and milk production of lactating dairy cows. Journal of Dairy Science. 82:391-403.

(Received February 1, 2013/Accepted February 20, 2013) 